\title{
Phytoprotection
}

\section{Petiole rot caused by Fusarium monoliforme, a new disease or Areca palm}

\section{G.M. Dal Bello et G.A. Lori}

Volume 78, numéro 3, 1997

URI : https://id.erudit.org/iderudit/706127ar

DOI : https://doi.org/10.7202/706127ar

Aller au sommaire du numéro

Éditeur(s)

Société de protection des plantes du Québec (SPPQ)l

ISSN

0031-9511 (imprimé)

1710-1603 (numérique)

Découvrir la revue

Citer cet article

Dal Bello, G. \& Lori, G. (1997). Petiole rot caused by Fusarium monoliforme, a new disease or Areca palm. Phytoprotection, 78(3), 125-127.

https://doi.org/10.7202/706127ar
Résumé de l'article

Chez le palmier Areca (Chrysalidocarpus lutescens), cultivé dans une serre à La Plata (Buenos Aires, Argentine), on a observé des symptômes d'une maladie qui n'avait pas été décrite précédemment. Les jeunes pétioles du bas pourrissaient d'abord, puis la feuille ensuite. Chez les pétioles malades, on a observé un mycélium aérien qui a donné une espèce de Fusarium en culture. D'après les caractéristiques morphologiques et culturales, tous les isolats ont été identifiés comme appartenant au $F$. moniliforme. Le pouvoir pathogène du champignon isolé a été démontré par inoculation sur des palmiers Areca. F. moniliforme a été ré-isolé à partir des palmiers inoculés et devenus infectés, selon les exigences du postulat de Koch. 


\title{
Communication brève / Short communication
}

\section{Petiole rot caused by Fusarium moniliforme, a new disease of Areca palm}

\author{
Gustavo M. Dal Bello and Gladys A. Lori ${ }^{1}$
}

Received 1997-05-05; accepted 1997-09-29

PHYTOPROTECTION 78 : 125-127

Symptoms of a previously undescribed disease were observed on greenhouse-planted Areca palms (Chrysalidocarpus lutescens), grown in La Plata (Buenos Aires, Argentina). Lower young petioles were rotted with the decay extending to the entire leaves. White mycelium was observed on diseased petioles from which a Fusarium sp. was recovered. Based on morphological and cultural criteria all isolates were identified as $F$. moniliforme. Pathogenicity was demonstrated on Areca plants inoculated with the fungus. F. moniliforme was reisolated from the inoculated palms to complete Koch's postulates.

\section{[Pourriture du pétiole causée par le Fusarium moniliforme chez le palmier Areca]}

Chez le palmier Areca (Chrysalidocarpus lutescens), cultivé dans une serre à La Plata (Buenos Aires, Argentine), on a observé des symptômes d'une maladie qui n'avait pas été décrite précédemment. Les jeunes pétioles du bas pourrissaient d'abord, puis la feuille ensuite. Chez les pétioles malades, on a observé un mycélium aérien qui a donné une espèce de Fusarium en culture. D'après les caractéristiques morphologiques et culturales, tous les isolats ont été identifiés comme appartenant au F. moniliforme. Le pouvoir pathogène du champignon isolé a été demontré par inoculation sur des palmiers Areca. F. moniliforme a été ré-isolé à partir des palmiers inoculés et devenus infectés, selon les exigences du postulat de Koch.

Areca palm (Chrysalidocarpus lutescens $\mathrm{H}$. Wendl.) is an ornamental palm, widely cultivated in world nurseries. Due to its high marketable value this specie is sold for outdoor planting and in pots for indoor use (Mc Currach 1980).

In August 1996, young palms in a greenhouse near La Plata city (Buenos Aires, Argentina, lat. $34^{\circ} 57^{\prime} \mathrm{S}$, long. $\left.57^{\circ} 57^{\prime} \mathrm{W}\right)$, were severely affected by a foliar disease. On some plants an entire necrosis of the young leaves was associated with progressing brown lesions at the base of petioles. The leaves were easily removed when pulled off from the plants. A rot covered by a white mycelium was then observed on the leaf sheaths.

1. Laboratorio de Fitopatología, Universidad Nacional de La Plata. CIC y CONICET. 60 y 119 , CC 31, (1900) La Plata, Buenos Aires, Argentina 
Twelve samples of infected plant tissues were surface-sterilized by dipping in $5 \% \mathrm{NaClO}$ for $1 \mathrm{~min}$ and rinsing twice in sterile distilled water. Four sheath pieces were plated on each of three Petri dishes containing $2 \%$ potato dextrose agar (PDA). Plates were incubated for $5 \mathrm{~d}$ at $25^{\circ} \mathrm{C}$ in continuous darkness. Colonies were transferred to PDA and incubated in a growth chamber at $22 \pm$ $2^{\circ} \mathrm{C}$ for $7 \mathrm{~d}$ with alternating light $(3500$ lux-dark cycles of $12 \mathrm{~h}$ plus the addition of near-UV light) to induce sporulation. Single-spore isolates were then obtained from each colony and stored on PDA at $5^{\circ} \mathrm{C}$.

A fungus morphologically identical to Fusarium was isolated from all the necrotic petiole tissues. Identification of Fusarium to species was made by examining conidiogenous cells from colonies cultured on $\mathrm{KCl}$ medium (Fisher et al. 1983).

Two tests were carried out to determine the pathogenicity and symptoms caused by the fungus. In the first experiment a conidial suspension was sprayinoculated onto healthy leaves of 60 to $70 \mathrm{~cm}$ tall Areca plants. The inoculum was prepared by scraping 7-d-old cultures on PDA with a glass rod after adding sterile distilled water containing one drop of Tween 20 per $500 \mathrm{~mL}$. The conidial suspension was filtered through a single layer of cheese-cloth and its concentration was adjusted to $1 \times 10^{8}$ conidia $\mathrm{mL}^{-1}$. Three plants were inoculated by using a hand-powered atomizer. Spore suspension was sprayed onto leaf surface until runoff. Controls were treated with water containing Tween 20.

In the second experiment three plants were utilized. A small wound was made at the base of each plant with a sterile needle. A $3 \mathrm{~mm} \times 3 \mathrm{~mm}$ square of PDA containing fresh mycelium was inserted into each incision. The wound was then sealed off with Parafilm. For control treatments, blocks of PDA without the fungus were applied. The inoculated plants and controls were placed in a moist chamber for $24 \mathrm{~h}$. The chambers were set up on a bench in the greenhouse at $20-25^{\circ} \mathrm{C}$ and $85 \% \mathrm{RH}$. The plants were observed daily for symptom development.

Each isolate from the necrotic tissues was identified as F. moniliforme Sheldon according to the systems of Booth (1971) and Nelson et al. (1983). Microconidia were born in long chains and false heads. The microconidiophores were long, unbranched and branched monophialides.

After an incubation period of about $20 \mathrm{~d}$, symptoms were observed on the spray-inoculated leaves. Infections took place on the younger leaves which showed yellowing, stunting and withering. The base of affected petioles exhibited brown tissue discoloration and rotting. Finally, the disease caused death of the leaves.

The second pathogenicity test resulted in cankers that grew slowly since day 25 after inoculation. In response to infection the host produced callus tissue. The base of infected petioles showed longitudinal cracking and the diseased area became enlarged and black. As the necrosis progressed, the young leaves showed symptoms similar to those described above and died within $6 \mathrm{wk}$. The pathogen recovered from $100 \%$ of the infected plants was identical with the original fungus, thus satisfying Koch's postulates. Control palms were healthy and exhibited no symptoms or death.

Fusarium moniliforme has been reported causing leaf spots and seed rot on Rhapis sp. and Chamaedorea sp. in United States ( Farr et al. 1989). Decline of date palms characterized by root rot has been associated with the fungus in Arabia (Elarosi et al. 1983) and the pathogen has also been isolated from diseased palm spathes in Iraq (AIRoubaie et al. 1987).

There are only few published reports of $F$. moniliforme on palms. Nevertheless the fungus is known to be a parasite of many cultivated plants. Since $F$. moniliforme is an airborne pathogen associated with warm climates as well as Areca palms, the petiole rot is likely to increase its occurrence and become a severe disease. 
This is the first report of a disease on Areca palm caused by $F$. moniliforme.

\section{REFERENCES}

Al-Roubaie, J.T., N.N. Hama, and K.K. AIHassan. 1987. [Studies on spread of inflorescence rot and susceptibility of some male palm cultivars to the disease] (in Arabian). J. Agric. Water Resour. Res. Plant Prod. (Iraq) $6: 67-79$.

Booth, C. 1971. The Genus Fusarium. Commonw. Mycol. Inst., Kew Surrey, England. $237 \mathrm{pp}$.

Elarosi, H., H. El-Said, M.A. Nagiels, and N. Jaheen. 1983. [AI-Wijam, decline date palm disease] (in Arabian). Pages 388403 in Proc. of the $1^{\text {st }}$ symposium on the date palm in Saudi Arabia.
Farr, D.F., G.F. Bills, G.P. Chamuris, and A.Y. Rossman. 1989. Fungi on plants and plants products in the United States. APS Press, St. Paul, Minnesota. 1252 pp.

Fisher, N.L., W.F.O. Marasas, and T.A. Toussoun. 1983. Taxonomic importance of microconidial chains in Fusarium section Liseola and effects of water potential on their formation. Mycologia $75: 693-698$.

Mc Currach, J.C. 1980. Palms of the world. Harper \& Brothers, New York 290 pp.

Nelson, P.E., T.A. Toussoun, and W.F.O. Marasas. 1983. Fusarium species : illustrated manual for identification. Penn. State Univ. Press, Univ. Park and London. $193 \mathrm{pp}$. 